Ludwig Schmahl, Rozwój historyczny Blankenheim, od czasów rzymskich do okresu wpływu administracji francuskiej i pruskiej oraz perspektywy przyszłego rozwoju, [w:] Krajobraz semantyczny wsi i miast, red. Józef Marecki, Lucyna Rotter, Kraków 2016, s. 53-70 (Symbol - Znak - Rytuał).

DOI: http://dx.doi.org/10.15633/9788374385183.05

Prof a.D. dr Ludwig Schmahl

PWSZ im. Witelona w Legnicy

\title{
Rozwój historyczny Blankenheim, od czasów rzymskich do okresu wpływu administracji francuskiej i pruskiej oraz perspektywy przyszłego rozwoju
}

\begin{abstract}
Blankenheim samt der zahlreich erhaltenen historischen $\mathrm{Ob}$ jekte und Bauten, wie z.B. die Burg Blankenheim mit ihrer Schlossanlage oder der Posthof, aber auch die Ahrquelle im Stadtzentrum sind wertvolle Kulturgüter. Die Stadt bietet Möglichkeiten für die Verbindung von Geschichte und Tradition mit der modernen, urbanen Sichtweise.
\end{abstract}

Key words: Blankenheim, Kulturgüter, urbanen Sichtweise

Gmina Blankenheim położona jest w Niemczech po zachodniej stronie Renu w górach Mittelgebirge należących do pasma górskiego Eifel. Obszar ten według ostatnich badań zasiedlony jest od 7ooo lat. Eifel to pierwsze pasmo górskie na południu Morza Północnego w kierunku równiny Holenderskiej. Najwyższym szczytem jest Hohe Acht leżący $747 \mathrm{~m}$ nad poziomem morza. Blankenheim znajduje się na wysokości ok. 500 metrów nad poziomem morza. Obecnie miejscowość ta jest siedzibą gminy składającej się z 17 miast. Położona jest około 70 kilometrów od Kolonii, 90 km od Trewiru oraz 110 km od Akwizgranu. 
Od czasów rzymskich krzyżowały się w niej dwa ważne szklaki komunikacyjne, które prowadziły z Kolonii do cesarskiego miasta Trewir oraz do Belgii. Miejscowość dysponuje znaczną połacią lasów, uchodzi za miejscowość wypoczynkową. Nad panoramą góruje zamek - ówczesna rezydencja hrabiów. Miejscowość liczy około 9.00o mieszkańców, posiada historyczne centrum oraz zasługującymi na uwagę atrakcjami. W nim znajduje się źródło rzeki Ahr, która po 85 km wpada do Renu. Nazwa rzeki pochodzi od celtyckiej Aha, oznaczającej wodę. Przeciętnie ze źródła wypływa 700 litrów wody na minutę. Zbocza i stoki rzeki Ahr są otoczone licznymi winnicami. Wytłaczane grono jest cenione szczególnie, jako wino czerwone. Dolina Ahr obejmuje największy zamknięty obszar upraw winnic w Niemczech. Miejscowość w ostatnich latach zmaga się ze spadającą liczbą mieszkańców. Możliwości pracy dla młodych nie są zbyt duże. Charakterystyczne dla tej miejscowości są: rolnictwo, przemysł, liczne sklepy oraz znaczna ilość turystów sięgająca rocznie 250.000 .

Historyczna dzielnica miejscowości Blankenheim nie ma charakteru rolniczego lecz jako uprzednie miejsce rezydencji szlacheckiej wraz z przynależnym zamkiem będącym ośrodkiem administracji skupiało również cechy rzemieślników, np. wytapiano z rud żelazo. Centrum miasta utraciło małe sklepy z powodu otwarcia na jego obrzeżach sklepów wielkopowierzchniowych. Na głównej ulicy aktualnie liczne stare budowle mają charakter pustostanów. Znajdują się tam dwa kościoły katolickie, jeden ewangelicki oraz Wolny Kościół, jak również meczet muzułmański.

Od czasów rzymskich znajduje się tam kompleks nadworny tzw. villa rustica (willa rzymska) zaliczany do największej rzymskiej rezydencji willowej na północy pasma górskiego Eifel. Na listę pomników archeologicznych wpisano willę w $1997 \mathrm{r}$.

Blankenheim podobnie jak Akwizgran i Kolonia partycypuje w utrzymaniu wojsk Imperium Rzymskiego. Rzymskie miasto cesarskie Trewir miało wówczas ok. 100.000 mieszkańców. Zdobyty przez Rzymian teren zabudowano według tamtejszej kultury celtyckiej, co 
znajduje odbicie w strukturze ulic. Rzymianie akceptowali sposób życia rdzennych mieszkańców, jednocześnie poprawiając ich sytuację życiową. Tak powstały termy, akwedukty, a także dwory, tak zwane wille rzymskie, które były areną rolniczego i chłopskiego życia. Początki willi rzymskiej datują się od połowy I wieku po Chr. Lata świetności przypadają od końca I do IV wieku kiedy była wzorcowo zarządzana. Dopiero w 1894 r. odkryto ją ponownie w związku z badaniami archeologicznymi. W 2014 r. zrekonstruowano, jako muzeum część terenu oraz budynków.

Imponujący budynek główny o powierzchni $70 \times 22 \mathrm{~m}$ dysponował 75 pomieszczeniami, ogrzewaniem podłogowym, jak również pięknym skrzydłem, w którym mieściły się łaźnie kąpielowe. Wiele przybocznych budynków jak np. świątynia, remiza, stajnie oraz pomieszczenia dodatkowe dla służby otaczały kompleks. Powierzchnia dworu znajdowała się na tarasowanym zboczu i była w całości otoczona murem kamiennym. W tylnej części budynku głównego znajdował się ogród użytkowy. Na zboczu znajdował się duży, prostokątny dziedziniec, do którego przylegało sześć budynków dodatkowychํㅡ.

Czasy rzymskie przyniosły rozwój gospodarczo-kulturalny dla Blankenheim. Możliwe to było dzięki rozbudowanym połączeniom komunikacyjnym, opiece lekarskiej, systemowi monetarnemu, podwyższone standardy mieszkaniowe oraz administrację wraz z systemem prawnym. Północna część Blankenheim została zasiedlona przez byłych żołnierzy, którzy swoją odprawę lokowali w nieruchomości².

\section{1. Średniowiecze i czasy nowożytne}

W 721 r. w akcie założycielskim opactwa Prüm wymieniono po raz pierwszy nazwę „blancium”, w którym to nastąpiło przeniesienie własności

\footnotetext{
1 Um Burg und Quelle, „Heimatverein Blankenheim, Vereinszeitung”, nr 111, Dezember 2010.

2 Tamże.
} 
w formie do darowizny. Czasy średniowiecza wiążą się zasadniczo z zarządzaniem przez władców Blankenheim, którzy zostają wymienieni po raz pierwszy na początku XıI wieku w dokumencie kolońskim. Jednoznaczne wzmianki na temat zamku i miejscowości datują się również w tym samym okresie. W 1380 r. „panowie z Blankenheim” otrzymują tytuł hrabiowski. Miejscowość otoczona jest murami obronnymi, otaczającymi zamek, które zostały wyposażone w bramy wejściowe.

Zamek z 1115 r. położony na terenie przybrzeżnym powyżej źródła Ahr przebudowano na zamek barokowy z ogrodem zoologicznym oraz oranżerią. W latach 1468/1469 celem zaopatrzenia w wodę zainstalowano wodociąg doprowadzający wodę z doliny. Ze źródła w dolinie pompowano wodę poprzez system kanałów na dziedziniec zamku. W ówczesnym czasie było to wspaniałe osiągnięcie techniki³.

W 1461 r. cesarz Fryderyk III mianuje hrabiego Dietricha III z Blankenheim-Manderscheid na hrabiego Rzeszy. Wkrótce hrabiowie z Blankenheim stają się największym samodzielnym rodem panującym w Eifel. Hrabstwo powiększało się stale poprzez zawierania związków małżeńskich i umów donacyjnych w zakresie nieruchomości.

W Średniowieczu symbol władzy i poważania wyrażany był relikwiami. Kolonia była w posiadaniu relikwii świętych Trzech Króli. Także Akwizgran i położony w pobliżu Kornelimuenster posiadały duży zasób relikwii. Hrabiowie z Blankenheim pozyskali podczas swoich licznych podróży skarb liczący ponad 500 relikwii, w tym popiersie z relikwiami św. Grzegorza z roku 1440 oraz Laskę Mojżesza. Dzisiejszy kościół parafialny został wzniesiony u podnóża wzgórza zamkowego, jako kościół pielgrzymkowy, w którym odprawiano uroczystości świąteczne. Duża część skarbów trafiła do Czech (Terezin) gdzie jest przechowywana i dotychczas nie została ponownie otwarta. Jednak w ostatnich latach za pozwoleniem władz czeskich zbiory

3 Um Burg und Quelle, „Heimatverein Blankenheim, Vereinszeitung”, nr 114, Dezember 2013. 
zostały częściowo przetworzone cyfrowo ${ }^{4}$. Do tego należy także Heiltumsbuch (księga zbawcza reliktów kościoła), w której wyszczególniono wszystkie relikwie. Została napisana w XV wieku i odniesieni się do miejsc biblijnych. Z okazji jubileuszu hrabiowskiego w 2015 r. została wystawiona publicznie.

Według protokołu głównej komisji deputacji Rzeszy z 1803 r. do hrabstwa należało 25 miast i wsi liczących ok. 3.900 mieszkańców. Pierwsze wzmianki dotyczące Sądu Naczelnego ds. Hrabstwa mającego swoja siedzibę w Blankenheim pojawiły się w 1597 r. Od 1697r. funkcjonował „sołtys ziemski”, który stał na czele administracji lokalnej. W 1790 r. hrabstwo obejmowało teren 13.952 hektarów, jak również przyłączone obszary o powierzchni 6.888 hektarów. Rodzina hrabiowska dzięki zawieraniu licznych małżeństw, a także poprzez przejmowanie urzędów w klasztorach poszerzyła znacznie swoje wpływy ${ }^{5}$.

W roku 1705 nastąpiło mianowanie hrabiów przez cesarza na komisariuszy. Oznaczało to, iż rezydujący hrabiowie stali się pełnomocnikami niemieckiego cesarza i odbierali hołd od mieszkańców w Kolonii. Kolończycy musieli pokłonić się więc hrabiom Rzeszy z Blankenheim.

Na szczególną wzmiankę zasługuje życiorys brata hrabiego Franza Georga $^{6}$. Urodził się jako hrabia Johann Moritz Gustav w Blankenheim. Mając 9 lat otrzymał urząd kanonika w Kolonii, następnie w Strassburgu, potem objął urząd biskupi we Wiedniu oraz został mianowany arcybiskupem w Palermo. Ostatecznie został arcybiskupem Pragi, jak również prymasem królestwa Czech. Rezydował tam od 1735 do 1763r. Pośredniczył w małżeństwie rezydującej hrabiny

4 Um Burg und Quelle, „Heimatverein Blankenheim., Vereinszeitung”, nr 113, Dezember 2012.

5 H. Heindrichs, Die Geschichte des des Blankenheimer Grafengeschlechtes, Blankenheim 1978.

6 Heimatkalender des Kreises Schleiden 1958, Darin: Der letzte Graf von Sternberg - Manderscheid, Blankenheim, s. 28-35. 
Rzeszy Augusty z hrabią czeskim Philippem Christanem von Sternberg. W 1758r. utworzył „dziedziniec Blankenheim” w kolońskim Starym Mieście7.

Reliktem z okresu barokowego jest kaplica Hülchrath. Jest ona położona na wzgórzu w Blankenheim z którego rozpościera się widok na historyczne zamek. Droga tam prowadzi wzdłuż tzw. siedmiu Fußfällen (klęknięć), które szczególnie po śmierci Blankenheimerów były celebrowane w ramach modlitwy. W $1781 \mathrm{r}$. dokończono kaplicę pod wezwaniem św. Krzyża, jako znak pokuty trzeciej małżonki hrabiego Josefa Franza Georga Ludwiga. We wnętrzu znajduje się liczna sztukateria w stylu rokoko oraz lustrzany sufit ${ }^{8}$.

\section{Okres zarządu francuskiego}

Życie w Blankenheim zmieniło się wskutek francuskiej rewolucji. W 1794 r. do miejscowości wkroczyło wojsko francuskie. Szlachta i księża zostali straceni, klasztory rozwiązano, profanowano kościoły, natomiast mieszkańcy musieli oddawać hołd „bogini rozumu”.

Jako skutek pokoju w Lunéville w 1801 r. ${ }^{9}$ Blankenheim znalazł się jako miasto położone po lewej stronie Renu na terenie Francji. Majątki kościelne zostały zlicytowane. Nowa władza przejęła posiadłości rodziny hrabiowskiej, a domy otrzymały numerację jako symbol francuskiego władztwa. Wprowadzono nowe podstawy prawne - Kodeks Napoleona. W kilku fragmentach ten akt prawny obowiązuje po dzień dzisiejszy na obszarach leżących po lewej stronie Renu. Dla ludności

7 Um Burg und Quelle, „Heimatverein Blankenheim, Vereinszeitung”, nr 114, Dezember 2013.

8 Um Burg und Quelle, „Heimatverein Blankenheim, Vereinszeitung”, nr 111, Dezember 2010.

9 Napoleonische Friedensverträge. Campo Formio 1797 - Lunéville 1801 Amiens 1802 - Preßburg 1805 - Tilsit 1807, W. Ernst (Hg.), P. Hersche (Bearb.), Wien-Schönbrunn 1809. 
cywilnej, pomimo całej niesprawiedliwości było to przebudzenie do nowych czasów. Wartości wolności, równości i braterstwa, jak również idea oświecenia pobudziły zainteresowanie przede wszystkim młodszej generacji. Okropności rewolucji uwidoczniły się w późniejszym okresie w Kolonii oraz w Trewirze ${ }^{10}$.

W 1795 r. po zajęciu lewego brzegu Renu przez Francuzów utworzony został urząd centralny w Blankenheim. Należał ona do jednostki administracyjnej (okręgu) Prüm w Saar-Department. Język francuski był językiem urzędowym. Nowo chrzczone dzieci otrzymywały francuskie imiona.

W 1794 r. rodzina hrabiowska uciekając przed egzekucją przeniosła się do Pragi (ewakuowano dobytek na 32 wozach), gdzie wprowadziła się do obszernego pałacu hrabiego Sternberga. Zamek został splądrowany przez żołnierzy, ale także przez ludność i ostatecznie przeznaczony do rozbiórki. Zamek w chwili obecnej jest częściowo odrestaurowany. Rzymskie znaleziska trafiły do Paryża i można je podziwiać w Luwrze.

\section{Blankenheim pod rządami pruskimi}

Na mocy postanowień Kongresu Wiedeńskiego w 1815r. Blankenheim trafił na teren Prus. Rodzina hrabiowska nie odzyskała swoich posiadłości natomiast obiecano im, iż otrzymają dobra wcześniejszych klasztorów Weissenau i Schussenried w Oberschwaben tytułem odszkodowania.

Zgodnie z królewskim edyktem z 5 kwietnia 1815 r. zarówno nazwa, jak i same wielkie księstwo Niederrhein dołączono do pruskiego państwa. Do wymienionych miejscowości należał także Blankenheim. Utworzono tam sześć nadreńskich okręgów administracyjnych,

10 Veröffentlichungen der staatlichen Archive des Landes Nordrhein-Westfalen. Reihe B. Heft 8, Siegburg, Respublika Verlag 1997. 
przydzielono Blankenheim pod zarząd w Aachen, sprawowany zgodnie z pruskimi ideałami. Wskutek walki kulturowej państwa (Kulturkampf) z kościołem katolickim poprzez dyrektywy administracyjne powodujące brak księży spustoszono katolickie wspólnoty kościelne. Państwo pruskie było państwem żołnierzy, a wiele budowli zamkowych zmieniło swoją funkcję na koszary"1.

\section{Rozwój po II wojnie światowej}

Zachwyt narodowym socjalizmem w Blankenheim był powściągliwy. Podczas, gdy położona w pobliżu Kolonia została zniszczona w 95\%, Blankenheim pozostał oszczędzony przed brytyjskimi nalotami. Bombardowania spowodowały niewiele szkód. W 1945 r. do miejscowość wkroczyła belgijska armia i pozostała tam do momentu wejścia Niemiec do NATO w dniu 6 maja 1955 r. Faktycznie stacjonowała do 2002 r. W 1988 r. stacjonowało w Niemczech 26.000 belgijskich żołnierzy wraz z 25.000 kobiet i dzieci. Dla Blankenheim stacjonowanie wojsk oznaczało wzrost gospodarczy. Utworzono także osiedle, jak również szkołę dla dzieci. Na ulicy głównej, Ahrstrasse otworzono czternaście dobrze prosperujących restauracji. Utworzony również nowy teren działalności gospodarczej, który jednak doprowadził do regresji handlu w tej historycznej miejscowości. Wymarsz wojsk okupacyjnych skutkował zamknięciem większości lokali

Kompleks zamkowy odbudowano i pełni funkcję schroniska młodzieżowego. Turyści wpływają pozytywnie na rozwój handlu oraz korzystają z prowadzących przez Blankenheim dróg dla pielgrzymów lub dróg wędrownych o łącznej długości 400 kilometrów.

11 H. Henn, A. Reetz, Blankenheim - Die Orte der Gemeinde Blankenheim in alten Bildern, 1: Gemeinde Blankenheim, Blankenheim, 1982; H. Henn, A. Reetz, Blankenheim - Die Orte der Gemeinde Blankenheim in alten Bildern, t. 2: Gemeinde Blankenheim, Blankenheim, 1984. 


\section{Perspektywy na przyszłość}

Na szczególną uwagę zasługuje innowacyjny projekt przekształcenia Starego Miasta Blankenheim Architektura i planowanie miasta" opracowany na Uniwersytecie Technicznym w Aachen, prowadzony przez katedrę oraz Instytut Budowy miast i Planowania Przestrzennego. Wedtug profesora dr Rolfa Westerheide Starówka Blankenheim to „historyczny skarb, który powinien być wyniesiony jako skarb historyczny! ${ }^{12}$.

W ramach warsztatów w Blankenheim uwzględniono miejscowe warunki, np. istniejącą infrastrukturę, zasoby komunalne, warunki atmosferyczne (w tym nasłonecznienie) poszczególnych obiektów. W projekcie uczestniczyli aktywnie również przedstawiciele Rady Gminy, mieszkańcy wraz z burmistrzem. Zasadniczą kwestią do rozstrzygnięcia znalazł się problem sformułowany w pytaniu: „jak historyczne miejsce mogłoby zyskać na atrakcyjności?”.

Intensywne analizy w obszarach definiowania miejscowości w aspekcie historycznym skupione wokół głównej ulicy prowadziły ogólnie do określenia deficytów i potencjałów przyszłego rozwoju Blankenheim. Określono środki sformułowane w zaleceniach działania dla poszczególnych obszarów.

Punktem wyjścia do opracowania stało się stwierdzenie: „Blankenheim wraz z licznymi zachowanymi historycznymi obiektami i domami (w tym z muru pruskiego), jak zamek oraz poczta, a także źródło rzeki Ahr w centrum posiada duży potencjał. Niemniej jednak centrum miejscowości cierpi z powodu pustostanów mieszkaniowych i sklepów, obciążenia ruchem oraz nieuporządkowaną rozproszoną przestrzenią miasta."

12 Prof. Dipl.-Ing. Bauass. R. Westerheide, Dipl.-Ing. M.Re. A. Eaton, Dipl.-Ing. S. Kashi, Dipl.-Ing. Bauass. S. Krapp AOR, Studierende Winter und Sommersemester 2013/2014, Masterplan zur Umgestaltung der Blankenheimer Altstadtm - Die Dokumentation entstand im Rahmen des Studienprojektes am Lehrstuhl und Institut für Städtebau und Landesplanung Fakultät für Architektur, RWTH Aachen, 2014. 
Jako potencjały wymieniono:

- wspieranie oraz rozbudowa turystyki

- historyczny trzon jako centrum gminy z 17 miejscowościami,

- lokalizacja jako potencjał dla nasze mieszkania.

Sformułowano także konkretne założenia postępowania dla:

- kształtowania serca miejscowości,

- dostępu do miejscowości ( $\mathrm{z}$ dworcem dla autobusów),

- wejść do restauracji,

- ulicy głównej (droga przejezdna).

Przy tym perspektywy działania wiążą się od zastosowania nowych brukowych nawierzchni ulic, właściwego przechowywania odpadów, wykorzystania oświetlenia (naturalnego), kształtowania dostępu do źródła rzeki Ahr, aż po właściwe wyeksponowanie, wyróżnienie budynków historycznych.

W jednej z dwóch części planu przeanalizowano poszczególne budynki i rozwinięto pomysły do zastosowania w przyszłości. Nowe wyzwania leżą u podstaw kształtowania historycznego serca miejscowości oraz stworzenia nowych miejsc pracy poprzez krzewienie kultury i turystyki.

Na szczególną uwagę zasługują dwa znajdujące się w miejscowości domy spokojnej starości. Ponadto na specjalnie przygotowanym obszarze umożliwienie korzystania z jazdy konnej gwarantuje również miejsca pracy. Jeden z domów jest prowadzony przez zgromadzenie "Communio in Christo", które ma swoją główną siedzibę w Mechernich i zostało założone przez Holendrów w 1984r. Założycielką była Maria Teresa Linssen, holenderska mistyczka i charyzmatyczka mieszkająca czasowo w Blankenheim.

Zadaniem obecnym gminy, ale także jej mieszkańców jest to aby uwzględnić propozycje przedmiotowego planu oraz rozwinąć konkretny koncept działania. Pozostaje więc czekać i realizować przyjęte założenia, zadając pytanie czy odkryty „ukryty skarb” Blankenheim można ożywić w przyszłości. 


\section{Bibliografia}

Heimatkalender des Kreises Schleiden 1958, Darin: Der letzte Grafvon Sternberg - Manderscheid, Blankenheim, s. 28-35.

Heindrichs H., Die Geschichte des des Blankenheimer Grafengeschlechtes, Blankenheim 1978.

Henn H., Reetz A., Blankenheim - Die Orte der Gemeinde Blankenheim in alten Bildern, t. 1: Teil, Gemeinde Blankenheim, Blankenheim 1982. Henn H., Reetz A., Blankenheim - Die Orte der Gemeinde Blankenheim in alten Bildern, t. 2: Teil Gemeinde Blankenheim, Blankenheim 1984.

Napoleonische Friedensverträge. Campo Formio 1797 - Lunéville 1801 Amiens 1802 - Preßburg 1805 - Tilsit 1807, W. Ernst (Hg.), P. Hersche (Bearb.), Wien-Schönbrunn 1809.

Prof. Dipl.-Ing. Bauass. R. Westerheide, Dipl.-Ing. M.Re. A. Eaton, Dipl.-Ing. S. Kashi, Dipl.-Ing. Bauass. S. Krapp AOR, Studierende Winter und Sommersemester 2013/2014, Masterplan zur Umgestaltung der Blankenheimer Altstadtm - Die Dokumentation entstand im Rahmen des Studienprojektes am Lehrstuhl und Institut für Städtebau und Landesplanung Fakultät für Architektur, RWTH Aachen 2014.

Um Burg und Quelle, „Heimatverein Blankenheim, Vereinszeitung”, nr 111, Dezember 2010.

Um Burg und Quelle, „Heimatverein Blankenheim, Vereinszeitung”, nr 114, Dezember 2013.

Um Burg und Quelle, „Heimatverein Blankenheim., Vereinszeitung”, nr 113, Dezember 2012.

Veröffentlichungen der staatlichen Archive des Landes Nordrhein-Westfalen. Reihe B. Heft 8, Siegburg, Respublika Verlag 1997. 


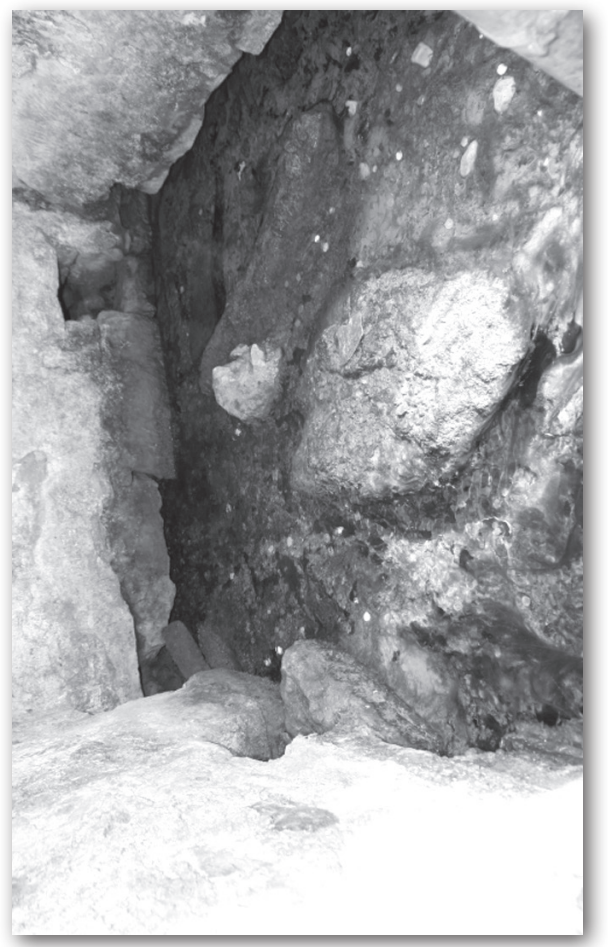

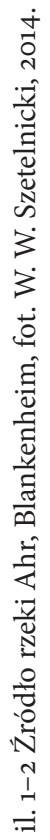

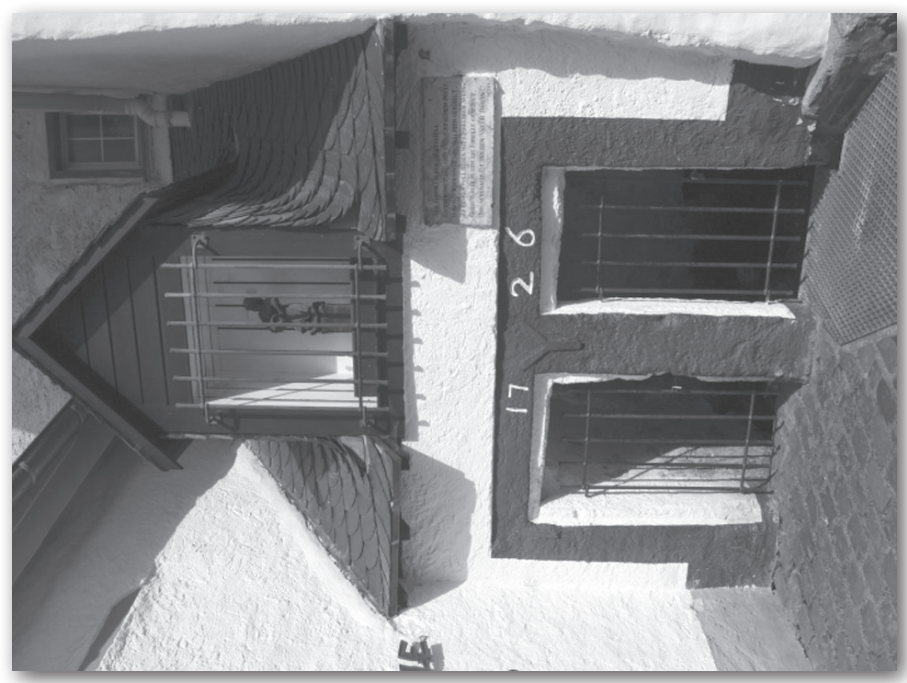




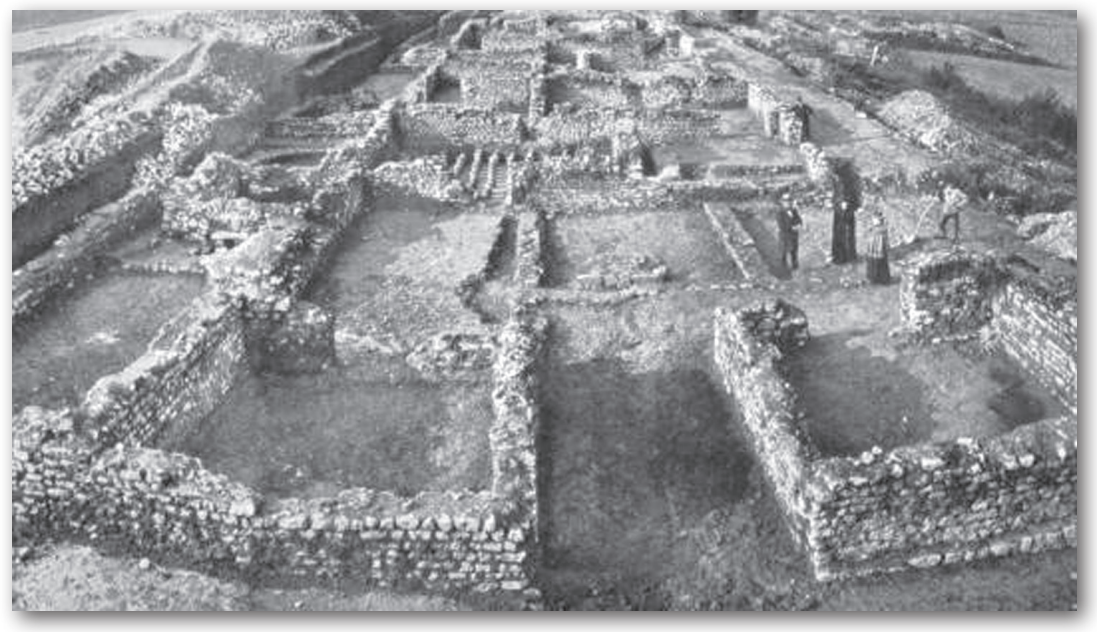

il. 3 Pierwsze badania archeologiczne, 1894 r.

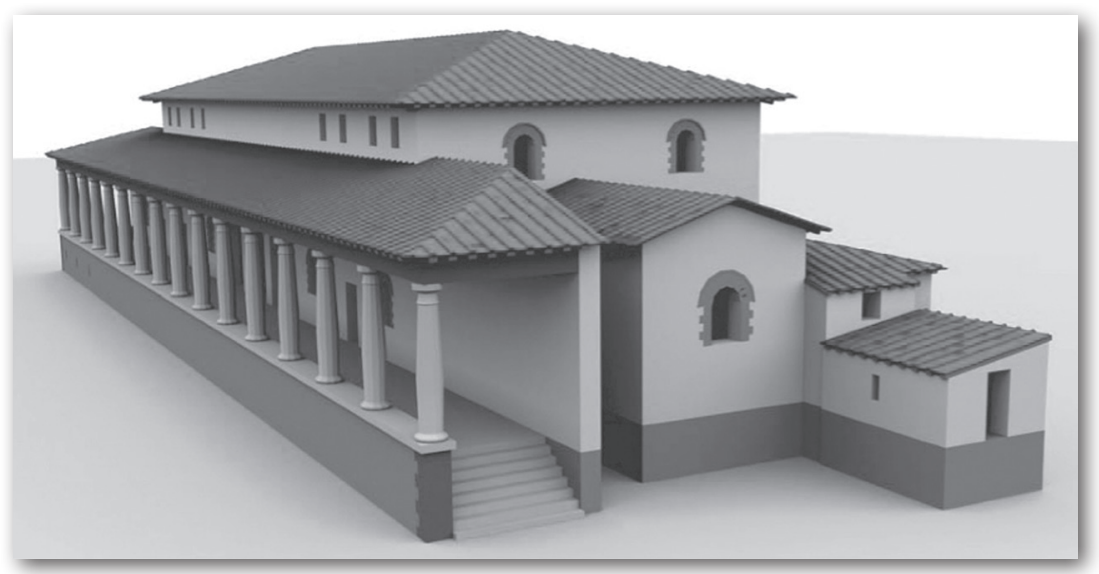

il. 4. Villa Rustica - Blankenheim. 


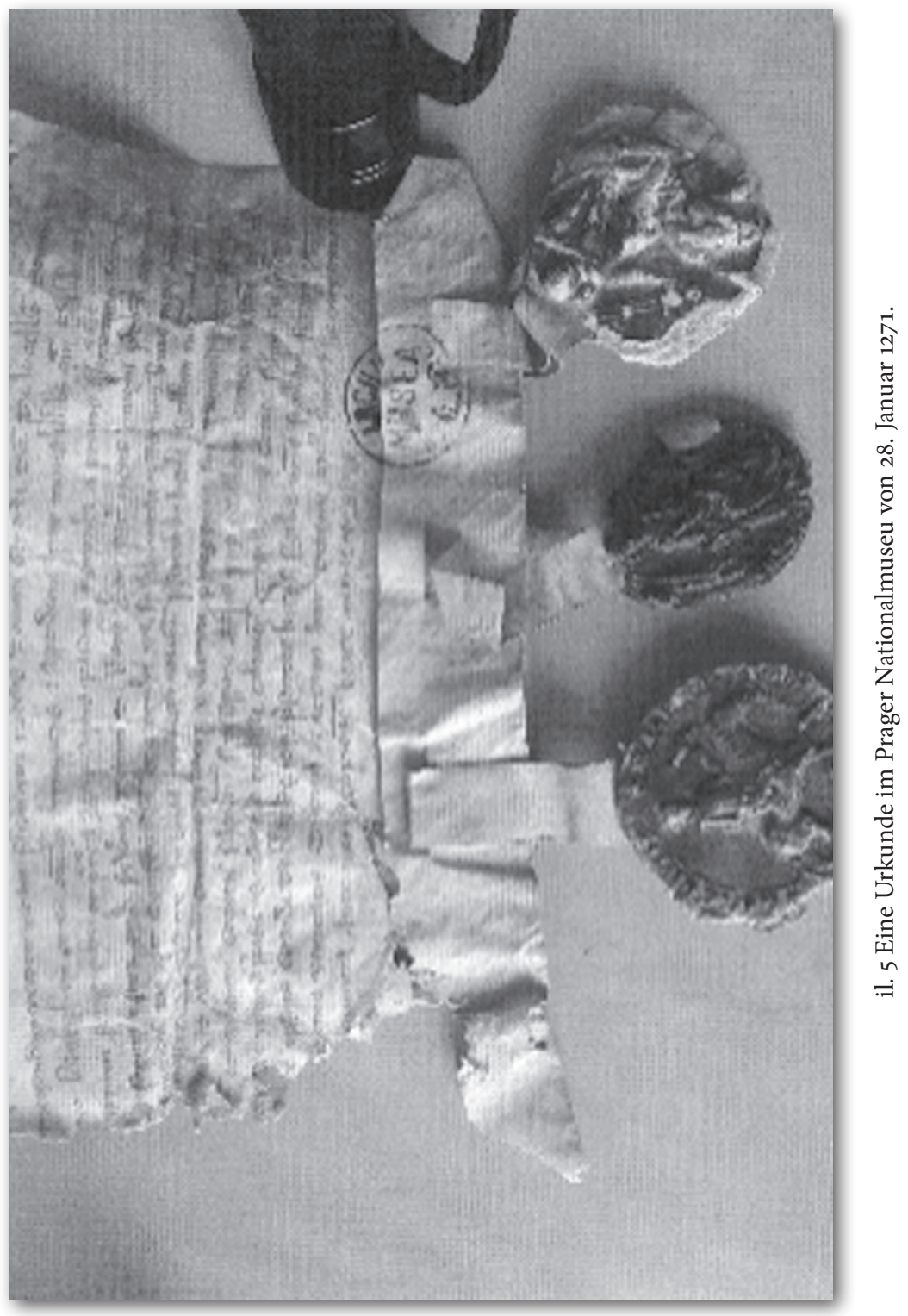




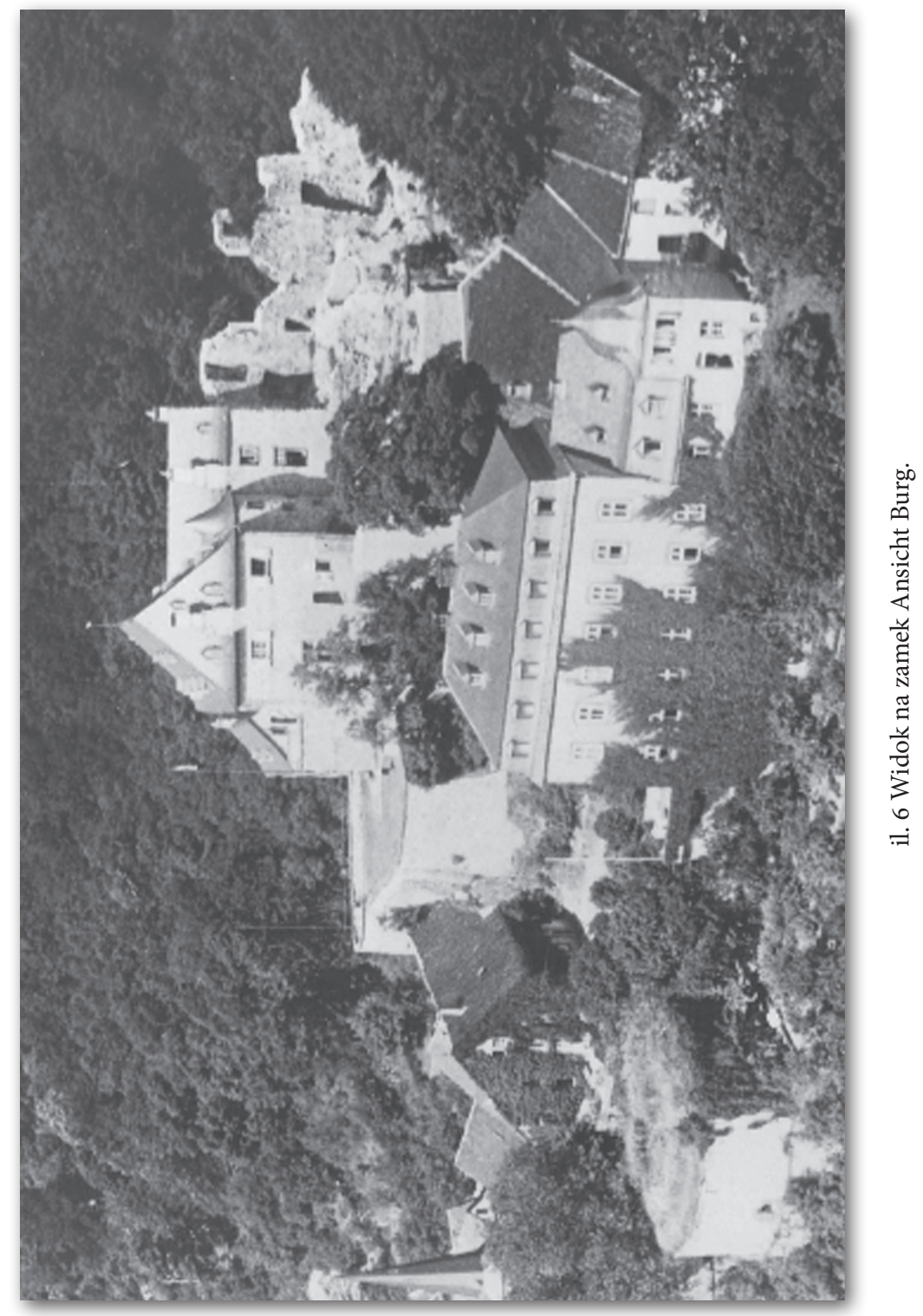




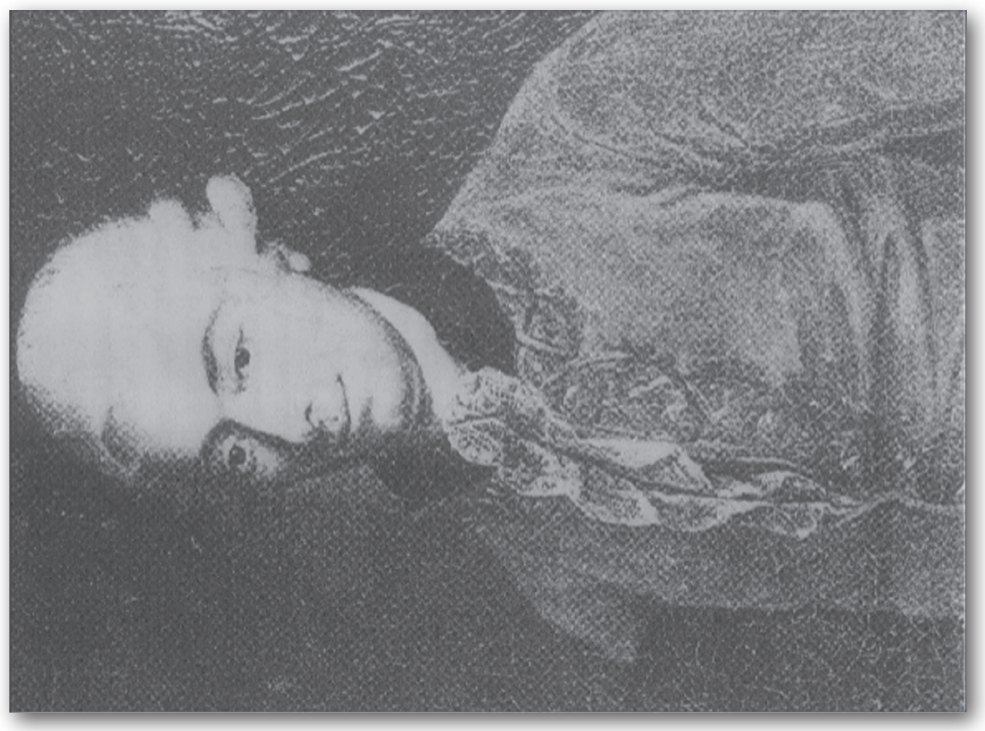

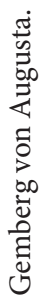
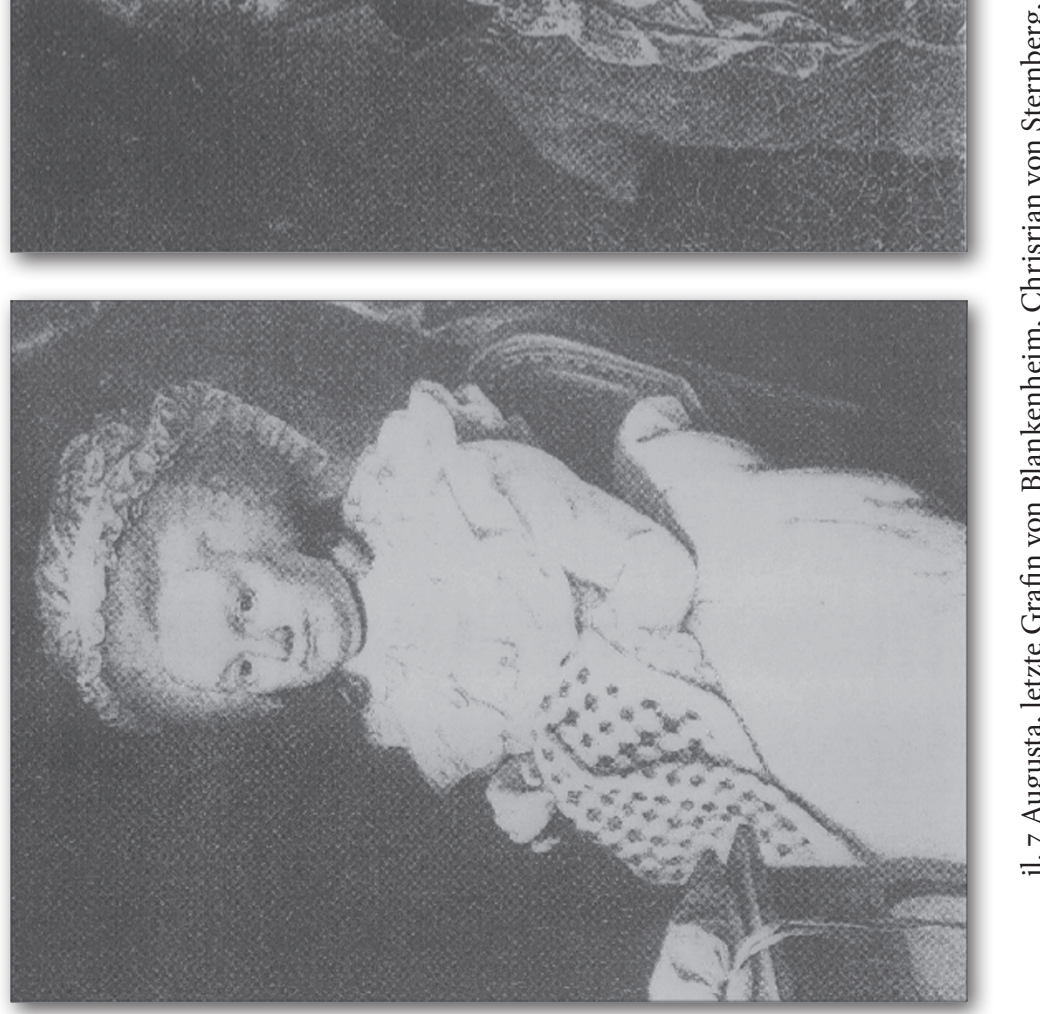

की

है 


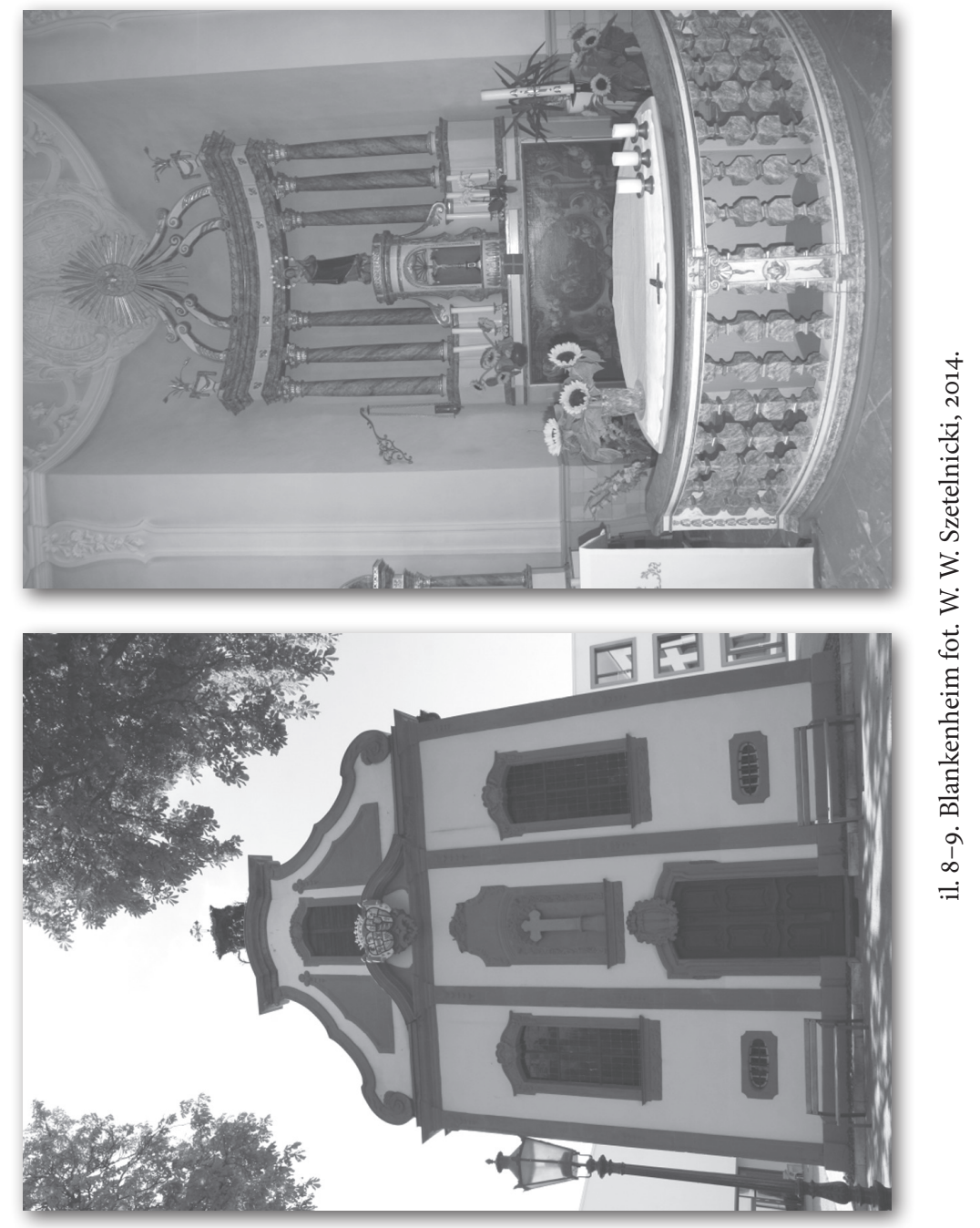


